\title{
High prevalence of Coxiella burnetii infection in humans and livestock in Assiut, Egypt: A serological and molecular survey
}

\author{
Hypy Abbass ${ }^{1,2}(\mathbb{D})$, Salah Abdel Kareem Selim²(D), Mona M. Sobhy ${ }^{(D)}$, Mohamed A. El-Mokhtar ${ }^{4}\left(\mathbb{D}\right.$, Mahmoud Elhariri ${ }^{5}$ (D) and \\ Hanan H. Abd-Elhafeez ${ }^{6}$
}

\begin{abstract}
1. Department of Microbiology, Microbiologist at South Egypt Cancer Institute of Assiut University. Egypt; 2. Department of Microbiology, Faculty of Veterinary Medicine, Cairo University, Egypt; 3. Department of Reproductive Diseases, Animal Reproduction Research Institute, Animal Research Centre, Giza, Egypt; 4. Department of Medical Microbiology and Immunology, Faculty of Medicine, Assiut University, Assiut 71515, Egypt; 5. Department of Microbiology, Faculty of Veterinary Medicine, Cairo University, Giza, Egypt; 6. Department of Anatomy, Embryology and Histology, Faculty of Veterinary Medicine, Assiut University, Egypt.

Corresponding author: Salah Abdel Kareem Selim, e-mail: drsalahsleim54@gmail.com

Co-authors: HA: hypyabbass@yahoo.com, MMS: monagabr17@yahoo.com, MAE: elmokhtarma@aun.edu.eg, ME: mahmoud_elhariri@cu.edu.eg, HHA: hhnnzz91@aun.edu.eg

Received: 26-06-2020, Accepted: 16-10-2020, Published online: 05-12-2020
\end{abstract}

doi: www.doi.org/10.14202/vetworld.2020.2578-2586 How to cite this article: Abbass H, Selim SAK, Sobhy MM, El-Mokhtar MA, Elhariri M, Abd-Elhafeez HH (2020) High prevalence of Coxiella burnetii infection in humans and livestock in Assiut, Egypt: A serological and molecular survey, Veterinary World, 13(12): 2578-2586.

\begin{abstract}
Background and Aim: Q fever is considered a neglected zoonotic disease and is caused by Coxiella burnetii. Very little information is available on C. burnetii infections in cattle, sheep, and goat populations in Egypt. The aim of this study was to identify the seroprevalence of $C$. burnetii in humans and livestock and to test for the presence of $C$. burnetii DNA in sera from seropositive animals and humans.
\end{abstract}

Materials and Methods: Blood samples were collected from 160 apparently healthy farm animals and 120 patients from three hospitals of the Assiut Governorate throughout 2017/2018. These populations were tested for antibodies against C. burnetii phase II antigen by immunofluorescence assay [IFA] and enzyme-linked immunosorbent assay (ELISA). Seropositive samples were subjected to real-time quantitative polymerase chain reaction (RT-qPCR).

Results: The results of the IFA revealed $C$. burnetii seroprevalence rates of $45.3 \%, 56.0 \%, 45.7 \%$, and $53.3 \%$ in cattle, sheep, goats, and humans, respectively. In humans, the seroprevalence rates were $52.1 \%, 30.4 \%, 37.5 \%, 74.1 \%$, and $62.5 \%$ in patients with fever of unknown origin, influenza, kidney dialysis, hepatitis $\mathrm{C}$ virus, and hepatitis $\mathrm{B}$ virus, respectively. Likewise, by ELISA, the seroprevalence in bovine was 50.7\%; sheep, 60.0\%; goats, 51.4\%; and humans, $55.0 \%$ (54.3\%, $30.4 \%, 37.5 \%, 77.8 \%$, and $62.5 \%$ in patients with fever of unknown origin, influenza, kidney dialysis, hepatitis $\mathrm{C}$ virus, and hepatitis B virus, respectively). RT-qPCR targeting the repetitive element IS1111 confirmed the presence of C. burnetii DNA.

Conclusion: These results proved that apparently healthy cattle, sheep, and goats may be very important reservoirs of C. burnetii infection. In light of these data, the effect of $Q$ fever on the replication of hepatitis virus remains unclear. Although hepatitis is one of the main aspects of acute Q fever, the influence of hepatitis on Q fever remains to be investigated. Q fever is not a reportable disease in Egypt, and clinical cases may rarely be recognized by the health-care system. Additional information on the epidemiology of C. burnetii in Egypt is warranted, including other associated problems such as the distribution of infections, pathologic hallmarks, and molecular typing.

Keywords: apparently healthy farm animals and humans, Coxiella burnetii, enzyme-linked immunosorbent assay, hepatitis $\mathrm{C}$ and $\mathrm{B}$, immunofluorescence assay, Q fever, real-time quantitative polymerase chain reaction.

\section{Introduction}

Fever may be a symptom of infection with Coxiella burnetii, a small obligate intracellular Gramnegative pathogen spreading worldwide, except in New Zealand [1-4]. Sheep, goats, and bovines are considered the main reservoir of human infection $[5,6]$. In animal hosts, abortions, and stillbirths are among the foremost pathological manifestations of chronic Q fever [7-9].

Copyright: Abbass, et al. Open Access. This article is distributed under the terms of the Creative Commons Attribution 4.0 International License (http://creativecommons.org/licenses/ by/4.0/), which permits unrestricted use, distribution, and reproduction in any medium, provided you give appropriate credit to the original author(s) and the source, provide a link to the Creative Commons license, and indicate if changes were made. The Creative Commons Public Domain Dedication waiver (http:// creativecommons.org/publicdomain/zero/1.0/) applies to the data made available in this article, unless otherwise stated.
In sheep and goat flocks with reproductive disorders, animals may shed the bacterium in vaginal mucus, feces, and milk [10]. Sheep, goats, and bovid are the main subclinical carriers, but they can shed bacteria in various types of secretions and excretory products. In a recent study, goats were shown to eliminate C. burnetii mostly through their milk, whereas sheep eliminated the bacterium through their vaginal mucus or feces [11]. C. burnetii was the cause of abortion waves at 28 dairy goat farms and a couple of dairy sheep farms in the Netherlands $[12,13]$. Infection may persist for many years and may be lifelong. Humans are usually infected through airborne transmission from animal reservoirs, particularly from domestic ruminants [14].

People living in or next to farms are at increased risk of acquiring infection due to potential contact with 
infected animals, and people working in laboratories are also at risk because of contact with potentially infected organs and tissues [15].

Infection is usually transmitted by inhalation of desiccated aerosol particles and through contact with infected animals, animal tissue, or other animal products, such as wool [14]. Because $C$. burnetii can be secreted in the milk, the consumption of contaminated food such as raw milk and dairy farm products represents a route of infection for humans [14]. Clinically, acute Q fever in humans may present with flu-like symptoms usually followed by pneumonia, whereas chronic infection may involve endocarditis and death [16].

C. burnetii undergoes phase variation during antigenic transition from wild-type phase I to virulent phase II throughout serial passages in embryonated eggs or in cell cultures [14]. Serology assays can detect antibodies in phase I and phase II of $C$. burnetii infection. Phase II antibodies typically prevail throughout infection, whereas chronic infection is characterized primarily by a phase I antibody response [17]. Indirect immunofluorescent assay (IFA) can be used in the serodiagnosis of $\mathrm{Q}$ fever [18-21] and may be applicable not only in diagnosing $\mathrm{Q}$ fever and its therapeutic follow-up but also in screening sera in massive numbers $[15,22]$. So far, seroprevalence data on the incidence of current infection in humans or animals are limited. The methods used for the identification of $C$. burnetii strains include nested polymerase chain reaction (PCR) [23], real-time quantitative PCR(RT-qPCR) [24], touch-down PCR [25], and trans-PCR targeting IS1111, the repetitive transposon-like region of C. burnetii [26]. These tools are very helpful for epidemiological investigations, especially for linking sources of infection, for higher understanding of epidemiological risk factors, and to a lesser extent, for evaluating control measures.

Little information is available regarding C. burnetii infections in bovid, sheep, and goats in Egypt. Therefore, the aim of this study was to identify the seroprevalence of $C$. burnetii by IFA and to detect the presence of $C$. burnetii DNA in samples from seropositive animals, which could be a source of $C$. burnetii transmission.

\section{Materials and Methods}

\section{Ethical approval and informed consent}

The National Ethics Committee of Assiut University and Cairo University and the Veterinary authorities in Assiut and Cairo Provinces approved this study. Informed consent was obtained from human participants.

\section{Sampling}

Blood samples were collected from apparently healthy animals, including 75 bovids, 50 sheep, 35 goats, and 120 humans (from three hospitals). The blood samples were collected from the brachial vein of humans and the jugular vein of the animals. The samples were collected under aseptic conditions from randomly selected farms in different localities in the Assiut Governorate, Egypt, during 2016/2017. Serum samples were transferred into sterile vacuum tubes and stored at $-20^{\circ} \mathrm{C}$ until processed [14].

\section{Indirect IFA for the detection of anti-C. burnetii antibodies}

For the IFA, we used a commercially available kit (COXIELLA BURNETII I+II IFA IgG/IgM/IgA, Vircell). Serum samples were tested for IgG and IgM anti-C. burnetii phase II antibodies using slides coated with $C$. burnetii phase II antigen. The IFA was carried out as recommended by the manufacturer. Serial two-fold dilutions of serum were prepared in phosphate-buffered saline with a goat antihuman IgGfluorescein isothiocyanate (FITC) immunoconjugate, IgM-FITC immunoconjugate, anti-C. burnetii antibody-positive rabbit serum, and anti-C. burnetii antibody-negative rabbit serum. The slides were examined by fluorescence microscopy under ultraviolet light using $\times 400$. The samples emitting a green fluorescent color at a titer $\geq 1: 64$ were considered positive [14,27].

Enzyme-linked immunosorbent assay (ELISA) for the detection of anti- $C$. burnetii antibodies

ELISA kits were used for indirect multi-species ELISA-based detection of anti-C. burnetii antibodies in serum and milk samples from multiple host species (ID Screen ${ }^{\circledR}$ Q Fever Indirect Multi-species, product code FQS-MS-2P [lot number: C32]; ID-Vet, Gabrels, France).

The presence of anti-C. burnetii IgM antibodies are highly suggestive of recent or active $C$. burnetii infection. Meanwhile, the presence of anti-C. burnetii IgG antibodies indicate the previous infection [28].

\section{RT-qPCR}

\section{Extraction of DNA}

For whole-blood samples, DNA purification was performed using the QIAamp ${ }^{\circledR}$ DNA Mini Kit (Qiagen, Hilden, Germany, Cat. no. 51304) according to the manufacturer's instructions [29].

\section{RT-qPCR assay optimization and validation}

\section{Primer design}

The primers were selected based on published sequences of the transposon-like repetitive region of the $C$. burnetii genome (IS1111 gene). The IS1priff (5'-CGCAGCACGTCAAACCG-3') and Is1Pri_r ( $5^{\prime}$ - TATCTTTAACAGCGCTTGAACGTC- $3^{-}$) primers were used for qPCR together with the Tqpro_Is1 probe (FAM-5'ATGTCAAAAGTAA $\bar{C} A A G A A T G A T C G T A A C-$ 3'-TAMRA) [29]. The oligos were obtained from Metabion, Germany.

\section{PCR optimization and validation}

Conventional PCR was used to improve the sensitivity of the current target RT-qPCR assay for $C$. 
burnetii DNA. Conventional PCR was performed in a final volume of $50 \mu \mathrm{L}$ of reaction mixture containing $25 \mu \mathrm{L}$ of DreamTaq Green PCR Master Mix (Thermo Fisher Scientific, Waltham, MA, USA) [30], $0.8 \mu \mathrm{L}$ of 25 pmol of each IS1pri_f and IS1pri_r, $5 \mu \mathrm{L}$ of extracted DNA, and water sufficient to make up the reaction mixture volume. The following conditions were applied: Initial hot start at $95^{\circ} \mathrm{C}$ for $5 \mathrm{~min}$, followed by 40 cycles of denaturation at $95^{\circ} \mathrm{C}(30 \mathrm{~s})$, annealing at $60^{\circ} \mathrm{C}(30 \mathrm{~s})$, and elongation at $72^{\circ} \mathrm{C}(30 \mathrm{~s})$. The cycle was finalized with elongation at $72^{\circ} \mathrm{C}$ for 5 min. PCR reaction products were separated by electrophoresis of $10 \mu \mathrm{L}$ of PCR products in $1.5 \%$ agarose gel in $1 \times$ TAE buffer, visualized by staining with ethidium bromide, and examined using an ultraviolet transilluminator. The molecular weight of the obtained product was determined based on the molecular weight marker (Gene Ruler TM 100 bp DNA Ladder [Fermentas, Canada]) [14]. A sample was considered positive when an amplicon of $146 \mathrm{bp}$ was demonstrated.

\section{RT-qPCR}

RT-qPCR was performed in a final volume of $20 \mu \mathrm{L}$. The reaction mixture contained $5 \mu \mathrm{L}$ of DNA, $10 \mu \mathrm{L}$ of $2 \times$ Platinum $^{\mathrm{TM}}$ SuperFi ${ }^{\mathrm{TM}}$ PCR Master Mix (Invitrogen, Carlsbad, CA), $2.0 \mu \mathrm{L}$ of Is1Pri_f $(10 \mathrm{pmol}), 2.0 \mu \mathrm{L}$ of primer Is1Pri_r $(10 \mathrm{pmol}), 0.3 \overline{\mu \mathrm{L}}$ of probe Tqpro_IS1, and water sufficient to make up the reaction volume. The PCR thermal profile used for optimized conventional PCR was applied, and reactions were carried out using a 7500 Fast Real-Time PCR system (Applied Biosystems, USA) [31].

\section{Results}

On the basis of the IFA, the seroprevalence rates of $C$. burnetii infection (IgG and $\operatorname{IgM}$ ) in cattle, sheep, goats, and humans were $45.3 \%, 56.0 \%, 45.7 \%$, and $53.3 \%$, respectively (Table- 1 and Figure- 1 ).

On the basis of the ELISA, the seroprevalence rates of $C$. burnetii infection in cattle, sheep, goats, and humans were $50.7 \%, 60.0 \%, 51.4 \%$, and $55.0 \%$, respectively. In humans, the seroprevalence was $54.3 \%$ in patients with fever of unknown origin, $30.4 \%$ in flu patients, $37.5 \%$ in kidney dialysis patients, $77.8 \%$ in hepatitis $\mathrm{C}$ virus patients, and $62.5 \%$ in hepatitis $\mathrm{B}$ virus patients (Tables-2-4).

The samples positive for anti-C. Burnetii antibodies were tested by RT-qPCR in cattle, sheep, and goats (Table-5). Detection of C. burnetii-specific DNA in genomic DNA from human blood samples in Assiut Hospitals was also tested by RT-qPCR (Table-6).

Figure-2 presented the Agarose gel electrophoresis of PCR amplicons (146 bp) in samples positive for anti-C. burnetii phase II IgG antibodies. Lane M: 100 bp molecular size DNA marker. Lanes 1 and 2: Positive sheep whole-blood samples, lanes 3 and 4: Positive goat whole-blood samples, lanes 5 and 6: Positive human whole-blood samples, and lane 7: Negative control.

\section{Discussion}

Q fever is a zoonotic disease caused by the bacterium Coxiella burnetii. A Q fever outbreak was documented in Australia in 1935, and subsequently, the infection has been spreading [32,33]. Q fever in humans may present as a flu-like illness with symptoms such as headache, myalgia, and/or atypical pneumonia. Symptoms such as hepatitis and endocarditis may be long lasting in chronic cases [20]. The prevalence of Q fever is higher in females than in males. In addition, a higher seropositivity rate has been found in pregnant farm animals [34].

C. burnetii-specific antibodies have been detected in most livestock species of significance to Egypt. Therefore, current and future research should focus particularly on camels and buffalos in order to better map the transmission mechanism of $C$. burnetii to humans and identify any possible risk factors linked to exposure [20].

The prevalence of $C$. burnetii infection in animals varies widely according to the species tested, geographic location, and diagnostic test used [35]. In the present study, the ELISA test revealed seropositive rates of $50.7 \%$ in cattle, $60.0 \%$ in sheep, $51.4 \%$ in goats, and $55 \%$ in humans (Table-2).

IFA is one of the most commonly used serological approaches to diagnose C. burnetii infection [36]. ELISA has been proven to have a sensitivity similar to that of IFA [36], which was also documented in the present study. Therefore, both of them can be used for serological diagnosis.

Table-1: Prevalence of anti-C. burnetii antibodies by IFA for the detection of specific IgM and IgG antibodies.

\begin{tabular}{|c|c|c|c|c|}
\hline \multirow[t]{2}{*}{ Species } & \multirow[t]{2}{*}{ No. of serum samples } & \multirow[t]{2}{*}{ No. of positive IFAT\% } & \multicolumn{2}{|c|}{ No. of positive IFAT } \\
\hline & & & $\operatorname{Ig} M \%$ & IgG \% \\
\hline Cattle & 75 & $\begin{array}{c}34 \\
45.3 \%\end{array}$ & $\begin{array}{c}10 \\
29.4 \%\end{array}$ & $\begin{array}{c}24 \\
70.6 \%\end{array}$ \\
\hline Sheep & 50 & $\begin{array}{c}28 \\
56 \%\end{array}$ & $\begin{array}{c}8 \\
28.6 \%\end{array}$ & $\begin{array}{c}20 \\
71.4 \%\end{array}$ \\
\hline Goats & 35 & $\begin{array}{c}16 \\
45.7 \%\end{array}$ & $\begin{array}{c}6 \\
37.5 \%\end{array}$ & $\begin{array}{c}10 \\
62.5 \%\end{array}$ \\
\hline Human & 120 & $\begin{array}{c}64 \\
53.3 \%\end{array}$ & $\begin{array}{c}18 \\
28.1 \%\end{array}$ & $\begin{array}{c}46 \\
71.9 \%\end{array}$ \\
\hline Total & 280 & $\begin{array}{c}142 \\
50.7 \%\end{array}$ & $\begin{array}{c}42 \\
29.6 \%\end{array}$ & $\begin{array}{c}100 \\
70.4 \%\end{array}$ \\
\hline
\end{tabular}

IFA=Immunofluorescence assay. C. burnetii=Coxiella burnetii 


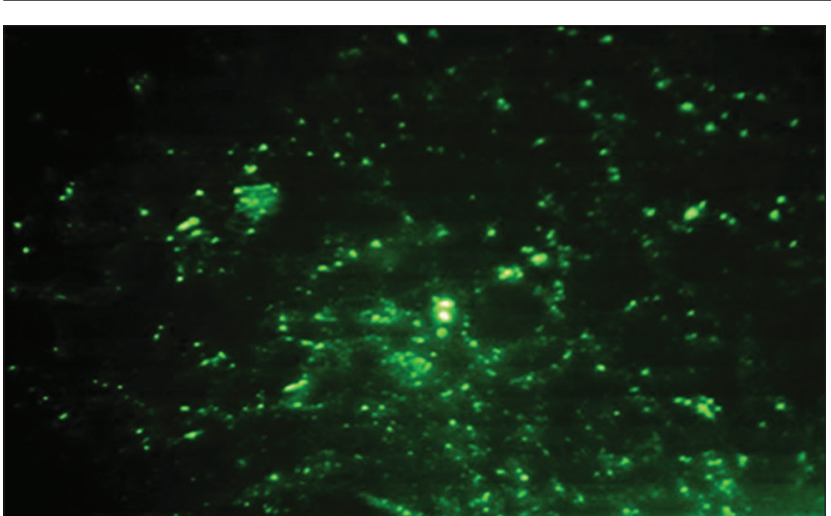

Figure-1: Seroprevalence of C. burnetii (IgG antibodies) in human samples as tested by indirect immunofluorescent antibody test (IFAT) IFA.

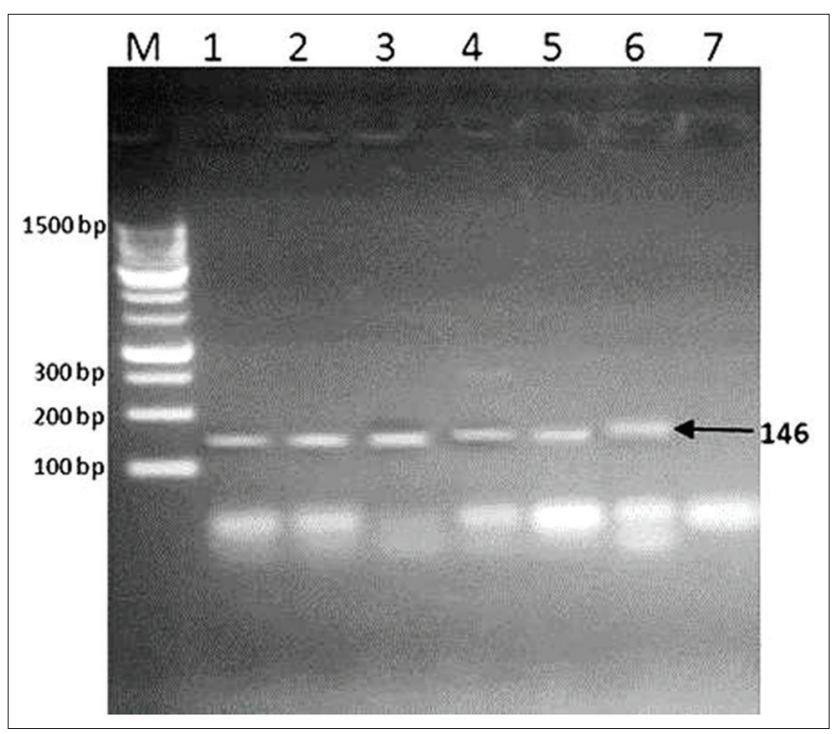

Figure-2: Agarose gel electrophoresis of polymerase chain reaction amplicons (146 bp) in samples positive for antiCoxiella burnetii phase II IgG antibodies. Lane M: 100 bp molecular size DNA marker. Lanes 1 and 2: Positive sheep whole-blood samples, lanes 3 and 4: Positive goat wholeblood samples, lanes 5 and 6: Positive human whole-blood samples, and lane 7: Negative control.

Table-2: Prevalence of anti-C. burnetii antibodies by ELISA.

\begin{tabular}{lccc}
\hline Species & $\begin{array}{c}\text { No. of serum } \\
\text { samples }\end{array}$ & \multicolumn{2}{c}{$\begin{array}{c}\text { Positive samples by } \\
\text { ELISA test }\end{array}$} \\
\cline { 3 - 4 } & & No. & $\%$ \\
\hline Bovine & 75 & 38 & 50.7 \\
Sheep & 50 & 30 & 60 \\
Goats & 35 & 18 & 51.4 \\
Human & 120 & 66 & 55 \\
Total & 280 & 152 & 54.3 \\
\hline
\end{tabular}

ELISA=Enzyme-linked immunosorbent assay,

C. burnetii=Coxiella burnetii

In the current study, anti-C. burnetii antibodies were detected by IFA in $45.3 \%$ of the cattle, $56.0 \%$ of the sheep, $45.7 \%$ of the goats, $53.3 \%$ of the apparently healthy humans, $52.1 \%$ of patients with fever of unknown origin, $30.4 \%$ in flu patients, $37.5 \%$ in kidney dialysis patients, $74.1 \%$ in hepatitis $\mathrm{C}$ virus patients, and $62.5 \%$ hepatitis $\mathrm{B}$ virus patients. The IFA is the most specific and sensitive test for phase II and phase I IgG antibodies, and for phase II and phase I IgM antibodies. The present work revealed that the presence of $C$. burnetii antibodies in hospitalized patients in Assiut Governorate by IFAT to be (53.3\%). Most of those patients had contact with animals and came from rural areas. Clinical manifestations included high temperature, chills, and bradycardia. Seropositivity may involve testing positive for antibodies from phase II and phase I C. burnetii infection. Phase II antibodies are more prevalent during acute infection, and chronic infection is characterized mainly by a phase I antibody response [36]. Results of the present work agree with the studies conducted in Egypt [37] and Sudan [38].

Infected small ruminants may shed high numbers of bacteria in their excretions, such as milk and feces. Animals may be shedding bacteria and/or remain seropositive long after the acute infection $[39,40]$. Other authors reported significantly higher seroprevalence in goats than in cattle [41].

The results of the ELISA tests indicated the high prevalence of $C$. burnetii infection in people in Ilam Province. Further, they demonstrate high seroprevalence of endemic Q fever in the countryside and in Bedouin populations. Furthermore, higher prevalence has been detected among people who have close engagement with livestock due to their occupations, such as animal husbandry workers $(45.13 \%)$ [42].

In the present study, 60 out of $150(40.4 \%)$ animals included tested positive for specific antibodies; a proportion that is close to that reported in humans.

There is also an agreement between the results of this study and the results of two similar studies performed in Turkey, where the C. burnetii seroprevalence reached $50.9 \%$ among people with close contact to livestock. Abattoir workers, farmers, and butchers were found to have the highest prevalence rates $(32.8 \%)[43,44]$.

Close contact with domestic animals has been reported to be one of the key risk factors related to the transmission of C. burnetii to humans $[45,46]$. Inhaling polluted materials from feces of infected animals or their urine, milk, and birth products is considered a key route of infection [47].

The seroprevalence of $C$. burnetii infection among slaughterhouse workers and butchers was found to be $22.5 \%$ in a study performed in 2016 in the Provinces of Sistani and Baluchistan, which are located in the Southeast of Iran [48].

In another study in Kurdistan Province, west of Iran, the seroprevalence of $C$. burnetii was reported $27.83 \%$ among hunters and their members of the family, butchers, employees of the public health centers, and patients who referred to laboratories [46]. In addition, high seroprevalence of $C$. burnetii infection was according in studies conducted in neighboring countries of Iran, particularly within the west and northwest of the country $[43,44]$.

Age and close contact with goats, rodents, and cats, as well as mosquito bites, are considered risk 
Available at www.veterinaryworld.org/Vol.13/December-2020/1.pdf

Table-3: The prevalence of anti-C. burnetii antibodies by IFA for the detection of IgM and IgG antibodies in patients in hospitals in the Assiut district.

\begin{tabular}{|c|c|c|c|c|c|c|c|c|}
\hline \multirow[t]{2}{*}{ Case report } & \multirow{2}{*}{$\begin{array}{c}\text { No. of } \\
\text { samples }\end{array}$} & \multirow{2}{*}{$\begin{array}{c}\text { No. of positive } \\
\text { IFAT } \%\end{array}$} & \multicolumn{2}{|c|}{ H1 } & \multicolumn{2}{|c|}{$\mathrm{H} 2$} & \multicolumn{2}{|c|}{ H3 } \\
\hline & & & IgM & IgG & IgM & IgG & IgM & IgG \\
\hline \multirow[t]{2}{*}{ Fever } & 46 & 24 & $3 / 16$ & $5 / 16$ & $2 / 20$ & $8 / 20$ & $2 / 10$ & $4 / 10$ \\
\hline & & $52.1 \%$ & $18.75 \%$ & $31.3 \%$ & $10 \%$ & $40 \%$ & $20 \%$ & $40 \%$ \\
\hline \multirow[t]{2}{*}{ Flu } & 23 & 7 & $1 / 5$ & $1 / 5$ & $2 / 14$ & $2 / 14$ & $1 / 4$ & $0 / 4$ \\
\hline & & $30.4 \%$ & $20 \%$ & $20 \%$ & $14.3 \%$ & $14.3 \%$ & $25 \%$ & $0 \%$ \\
\hline \multirow[t]{2}{*}{ Kidney dialysis } & 8 & 3 & $0 / 3$ & $1 / 3$ & $1 / 3$ & $1 / 3$ & $0 / 2$ & $0 / 2$ \\
\hline & & $37.5 \%$ & $0 \%$ & $33.3 \%$ & $33.3 \%$ & $33.3 \%$ & $0 \%$ & $0 \%$ \\
\hline \multirow[t]{2}{*}{ IHCV } & 27 & 20 & $2 / 8$ & $4 / 8$ & $3 / 12$ & $7 / 12$ & $1 / 7$ & $3 / 7$ \\
\hline & & $74.1 \%$ & $25 \%$ & $50 \%$ & $25 \%$ & $58.3 \%$ & $14.3 \%$ & $42.9 \%$ \\
\hline \multirow[t]{2}{*}{ IHBV } & 16 & 10 & $1 / 6$ & $2 / 6$ & $2 / 7$ & $3 / 7$ & $1 / 3$ & $1 / 3$ \\
\hline & & $62.5 \%$ & $16.7 \%$ & $33.3 \%$ & $28.6 \%$ & $42.9 \%$ & $33.3 \%$ & $33.3 \%$ \\
\hline \multirow[t]{2}{*}{ Total } & 120 & 64 & $7 / 38$ & $13 / 38$ & $10 / 56$ & $21 / 56$ & $5 / 26$ & $8 / 26$ \\
\hline & & $53.3 \%$ & $18.4 \%$ & $34.2 \%$ & $17.9 \%$ & $37.5 \%$ & $19.2 \%$ & $30.8 \%$ \\
\hline
\end{tabular}

IHCV =Infectious hepatitis C virus, IHBV=Infectious hepatitis B virus, H1= Hospital 1, H2= Hospital 2, H3=hospital 3. IFA=Immunofluorescence assay, $C$. burnetii=Coxiella burnetii

Table-4: The prevalence of anti- $C$. burnetii antibodies by ELISA in patients in hospitals in the Assiut district.

\begin{tabular}{lccccc}
\hline $\begin{array}{l}\text { Case } \\
\text { report }\end{array}$ & $\begin{array}{c}\text { No. of } \\
\text { samples }\end{array}$ & $\begin{array}{c}\text { No. of +ve } \\
\text { ELISA }\end{array}$ & H1 & H2 & H3 \\
\hline Fever & 46 & 25 & $9 / 16$ & $10 / 20$ & $6 / 10$ \\
& & $54.3 \%$ & $56.3 \%$ & $50 \%$ & $60 \%$ \\
Flu & 23 & 7 & $2 / 5$ & $4 / 14$ & $1 / 4$ \\
& & $30.4 \%$ & $40 \%$ & $28.6 \%$ & $25 \%$ \\
Kidney & 8 & 3 & $1 / 3$ & $2 / 3$ & $0 / 2$ \\
dialysis & & $37.5 \%$ & $33.3 \%$ & $66.7 \%$ & $0 \%$ \\
IHCV & 27 & 21 & $6 / 8$ & $10 / 12$ & $5 / 7$ \\
& & $77.8 \%$ & $75 \%$ & $83.3 \%$ & $71.4 \%$ \\
IHBV & 16 & 10 & $3 / 6$ & $5 / 7$ & $2 / 3$ \\
& & $62.5 \%$ & $50 \%$ & $71.4 \%$ & $66.7 \%$ \\
Total & 120 & 66 & $21 / 38$ & $31 / 56$ & $14 / 26$ \\
& & $55 \%$ & $55.3 \%$ & $55.4 \%$ & $53.8 \%$ \\
\hline
\end{tabular}

IHCV $=$ Infectious hepatitis $\mathrm{C}$ virus, IHBV $=$ Infectious hepatitis $B$ virus, $\mathrm{H} 1=$ Hospital $1, \mathrm{H} 2=$ Hospital 2, $\mathrm{H} 3=$ Hospital 3. ELISA=Enzyme-linked immunosorbent assay, $C$. burnetii=Coxiella burnetii

Table-5: RT-qPCR analysis for $C$. burnetii-specific DNA in seropositive samples. The seropositive samples were subjected to RT-PCR analysis and the ratios were calculated from positive samples of ELISA.

\begin{tabular}{lccc}
\hline Species & $\begin{array}{c}\text { No of +ve } \\
\text { samples }\end{array}$ & \multicolumn{2}{c}{ Positive samples by PCR } \\
\cline { 3 - 4 } & & No. & \% \\
\hline Cattle & 38 & 12 & 31.6 \\
Sheep & 30 & 14 & 46.7 \\
Goats & 18 & 8 & 44.4 \\
Human & 66 & 45 & 68.2 \\
Total & 152 & 79 & 51.9 \\
\hline
\end{tabular}

ELISA=Enzyme-linked immunosorbent assay, $\mathrm{RT}$-qPCR=Real-time quantitative polymerase chain reaction, $C$. burnetii=Coxiella burnetii

factors of C. burnetii seropositivity. Livestock, including goats, cattle, and sheep, are considered the most substantial animal reservoirs for human infection and considered the key reservoirs for urban outbreaks of $\mathrm{Q}$ fever [49].

This demonstrated the risk of $C$. burnetii infection among the Bedouin and countryside populations, who have extensive exposure to livestock [50].
Table-6: Detection of C. burnetii-specific DNA in blood samples from patients admitted to hospitals in the Assiut Governorate. The percentage of $C$. burnetii in hospitals $(H 1$, $\mathrm{H} 2$, and $\mathrm{H} 3$ ) and the percentage of $\mathrm{C}$. burnetii by RT-PCR were calculated from seropositive samples of ELISA.

\begin{tabular}{lccccc}
\hline $\begin{array}{l}\text { Case } \\
\text { report }\end{array}$ & $\begin{array}{c}\text { No. of +ve } \\
\text { samples }\end{array}$ & $\begin{array}{c}\text { No. of +ve } \\
\text { PCR }\end{array}$ & H1 & H2 & H3 \\
\hline Fever & 25 & 20 & 7 & 8 & 5 \\
& $54.3 \%$ & $80 \%$ & $35 \%$ & & \\
Flu & 7 & 4 & 1 & 2 & 1 \\
& $30.4 \%$ & $57 \%$ & $25 \%$ & $50 \%$ & $25 \%$ \\
Kidney & 3 & 1 & 1 & 0 & 0 \\
dialysis & $37.5 \%$ & 33.3 & $100 \%$ & & \\
IHCV & 21 & 14 & 4 & 5 & 5 \\
& $77.8 \%$ & $66.7 \%$ & $28.6 \%$ & $35.7 \%$ & $35.7 \%$ \\
IHBV & 10 & 6 & 2 & 3 & 1 \\
& $62.5 \%$ & $60 \%$ & $33.3 \%$ & $50 \%$ & $16.7 \%$ \\
Total & 66 & 45 & 15 & 18 & 12 \\
& $55 \%$ & $68.2 \%$ & $33.3 \%$ & $40 \%$ & 26.7 \\
\hline
\end{tabular}

ELISA=Enzyme-linked immunosorbent assay, RT-qPCR=Real-time quantitative polymerase chain reaction, $C$. burnetii $=$ Coxiella burnetii

Further, the results of the study detect and demonstrate high seropositive cases of Q fever in people who raise sheep, cattle, and goats; the Bedouin and countryside populations, and people who are in close contact with livestock due to their occupation. The existence of infected ticks in different parts of Iran has been demonstrated and reported in a couple of studies [51,52]. For example, C. burnetii was detected in 160 ticks gathered from domestic livestock (including goats and sheep) in 2009 in Kerman Province in the Southeast of Iran [53].

In a study performed on Namibian blood donors in 2014, a two-fold higher risk of infection was identified for those exposed to domestic animals recently diagnosed with tick-borne fever $(40 \%)$ than populations exposed to domestic animals negative for tickborne fever (22.9\%) [54].

Q fever outbreaks have been detected in various regions of Europe in both animals and people. Moreover, people exposed to animals through their 
profession have a higher risk of infection with $C$. burnetii than others. For example, high prevalence rates of $C$. burnetii infections among farmers tested using serological tests such as ELISA and IFA have been reported (31.12\% and 39.07\%, respectively) [24].

Age, place [55] (e.g., the countryside, where farmers are most often exposed to animals), and illiteracy (or low education) [56] are among the key factors contributing to a higher risk of $C$. burnetii infection in humans. For example, in Switzerland, individuals older than 15 years were reported to be at a higher risk (five-fold increased risk) than the younger respondents [55]. It was also reported that low education level is among the key risk factors contributing to an increased risk of developing Q fever [56].

Therefore, it could be assumed that raising the level of awareness regarding C. burnetii infection and its mode(s) of transmission could contribute to minimizing the prevalence of the infection.

Among the limitations of this study was its inability to infer valid conclusions regarding associations between risk factors and health outcomes.

The ELISA test detected anti-C. burnetii antibodies in $54.3 \%$ of patients with fever of unknown origin, in $77.8 \%$ of patients with hepatitis $\mathrm{C}$ virus, and in $62.5 \%$ of patients with hepatitis B virus. IFA and ELISA yielded similar seroprevalence data in patients undergoing kidney dialysis and patients with flu-like disease (37.5\% and $30.4 \%$, respectively) as they are seropositive $C$. burnetii. The IFA detected antibodies in $52.1 \%$ of the patients with fever of unknown origin, $77.8 \%$ of those with hepatitis $\mathrm{C}$ virus, and $62.5 \%$ of patients with hepatitis B virus. Hence, the seroprevalence in patients with chronic hepatitis $\mathrm{C}$ and hepatitis $\mathrm{B}$ virus infection with $C$. burnetii was remarkably high. Both variations of the hepatitis virus and $C$. burnetii cause liver cirrhosis.

This result was supported by a study [57] reporting that acute $\mathrm{Q}$ fever can be considered a possible cause of acute renal failure. In addition, other authors identified chronic Q fever in two dialysis patients [58].

The seroprevalence data pertaining to the patients with fever of unknown origin are supported by a recent study [59], which reported the case of a 53-year-old man diagnosed with fever of unknown origin who had been subjected to F-18 fluorodeoxyglucose positron emission tomography/computed tomography.

With regard to hepatitis, the results of the present study are interesting in the context of a recent study [60], where it was reported that $16(27.6 \%)$ out of 58 patients diagnosed with acute $\mathrm{Q}$ fever hepatitis were found to have viral hepatitis (hepatitis B virus infection in 12 and hepatitis $C$ virus infection in 4). Patients with Q fever have been found to have abnormal liver function. This is an issue of great concern for regions that are endemic to $\mathrm{Q}$ fever hepatitis as well as viral hepatitis [61]. A study stated that one out of nine patients with Q fever was diagnosed with jaundice, which suggests the involvement of the liver in Q fever [62].
In 1956, the finding of a granuloma-like lesion was first described in the above-mentioned study [61] using a needle biopsy on patients diagnosed with $\mathrm{Q}$ fever and liver involvement.

After that study, various other studies have also described the pathological features of Q fever hepatitis, referred to as doughnut lesions, which exist in the form of inflammatory tumor changes with fibrinoid rings as well as clear central spaces $[60,63,64]$.

The presence of Q fever in $17(13.3 \%)$ out of 128 patients diagnosed with infectious hepatitis was reported in the study by Alkan et al. [65]. The study further revealed that acute headache appeared to be the sole symptom, which could be used to discriminate Q fever from infectious hepatitis, but this discerning trait was not particularly specific. Apart from the problem of differentiating between $\mathrm{Q}$ fever, noninfectious hepatitis, and infectious hepatitis, there is still an urgent need to explore whether there are explicit differences in clinical manifestations, biochemical test values, and responses to treatment among patients who have underlying viral hepatitis. This is an issue of crucial importance, especially in countries where viral hepatitis is endemic, including Egypt. Similarly, differentiation between Q fever, noninfectious hepatitis, and infectious hepatitis is also of crucial importance.

Different studies show different rates of infection of $C$. burnetii infection in different countries. The seropositivity of $C$. burnetii infection in Japanese bovine herds reached $84.3 \%$ and was suggested to lead to reproductive disorders [18]. Other prevalence rates reached $14.39 \%$ in sheep in China and $13.5 \%$ in sheep in Northeastern China [1]. In Chad, the $C$. burnetii seropositivity values were $16 \%$ in humans, $13 \%$ in cattle, $23 \%$ in goats, and $33 \%$ in sheep [66]. The prevalence of $C$. burnetii infection in humans occupationally exposed to animals in Poland was $31.12 \%$ [67].

Q fever may lead to reproductive disorders as exemplified by a study emphasizing the existence of $\mathrm{Q}$ fever in all of the three major significant domestic ruminant species in Bangladesh [68]. It might play a key role in abortions in sheep because the seroprevalence is relatively high [7]. In the current study, quite a few serum samples from animals and humans showed anti-C. burnetii antibody positivity. IFA results were further confirmed by RT-qPCR. We evaluated the performance of RT-qPCR for the detection of C. burnetii-specific DNA targeting the IS1111 gene using serum samples from patients with acute Q fever. The use of molecular detection based on the IS1111 gene has $100 \%$ specificity [69]. Not all seropositive samples were positive by RT-PCR. This agrees with a recent study in which it was stated that serologic techniques may be hampered by limited accuracy because some animals may pose a risk for infection before the development of antibodies by shedding the bacteria and a few of the infected animals might never seroconvert [70]. 
Confirmatory testing by RT-qPCR revealed a proportion of PCR-positive samples among those that had tested positive by ELISA of $51.9 \%$ (cattle, $31.6 \%$; sheep, $46.7 \%$; goats, $44.4 \%$; and humans, $68.2 \%$ ). The calculated proportions from the total numbers of samples were $16 \%$ in cattle, $(31.6 \%)$ in sheep, $(28 \%),(26.7 \%)$ in goats, and $(37.5 \%)$ in humans.

C. burnetii real-time qPCR positivity was used on both acute-phase and follow-up convalescent-phase serum samples out of 65 serum samples with acute Q fever. Classification of sera was performed based on antibody profiles according to the IFA. We observed that PCR was positive in $49 / 50$ (98\%) seronegative sera, 9/10 (90\%) sera with isolated IgM-II antibodies, and 3/13 (23\%) sera with IgM-II antibodies [71]. Therefore, RT-PCR should be used to confirm seronegative samples in future studies to improve the accuracy in diagnosing $\mathrm{Q}$ fever.

A study provided data on PCR-based detection of $C$. burnetii in blood samples from small ruminants. ELISA and PCR were used to detect $C$. burnetii in native Korean goats (Capra hircus coreanae) for the first time. Out of 597 goats, 114 (19.1\%; 95\% confidence interval $[\mathrm{CI}]=16.1-22.4)$ and $57(9.5 \% ; 95 \%$ $\mathrm{CI}=7.5-12.2$ ) were $C$. burnetii positive by ELISA and PCR, respectively [72].

A study was undertaken in Northwest of Iran (or West of Azerbaijan). The main aim of that study was to identify the prevalence of $C$. burnetii in 840 raw milk samples gathered from domestic animals such as buffalos and cattle. DNA was extracted from all milk samples, and nested PCR was employed to detect C. burnetii using IS1111 as the target. It was shown that $16.9 \%$ of the milk samples $(19.3 \%$ of the buffalo and $14.6 \%$ of the cattle samples) tested positive for C. burnetii, which is in agreement with the results of our study on cattle (16\%) [73].

C. burnetii using RT-qPCR as well as serological surveys of animals is important methods for the diagnosis and control of Q-fever [27,74].

RT-PCR rapidly screen samples in local outbreaks for other organisms relevant for humans or animals sensitivity of real-time PCR was high after testing samples from a local Q-fever outbreak [68].

Finally, in Egypt, employing immunofluorescence assay (IFA) or ELISA for the diagnosis of $C$. burnetii and confirming it by (RT-qPCR) are important methods for the diagnosis and control of Q-fever. RT-PCR should be used to confirm seronegative samples in future studies to reach accurate early diagnosis of the $\mathrm{Q}$ fever.

Future research could include wide-scale surveys of patients to identify relationships between $Q$ fever, hepatitis B, hepatitis $\mathrm{C}$ and liver cirrhosis, fever of unknown origin, and reproductive disorders, such as habitual abortion, which may be linked to $C$. burnetii infection.

\section{Conclusion}

Apparently healthy cattle, sheep, and goats may be important reservoirs of $C$. burnetii infection. Although hepatitis is one of the major manifestations of acute Q fever, the influence of viral hepatitis on Q fever remains to be properly investigated. Q fever is not a reportable disease in Egypt, and clinical cases are probably unrecognized by the health-care system. More information on the epidemiology of $C$. burnetii in Egypt is warranted, as well as related topics such as distribution, pathogenesis, and molecular typing. IFA and confirming it by (RT-qPCR) are important methods for diagnosis and control of Q-fever in animals and human.

\section{Authors' Contributions}

HA, performed the practical part, contributed to the analysis and interpretation of data and writing the original draft. MMS contributed in the part of PCR and in reviewing the paper. SAKS contributed in reviewing the paper. MAE contributed in the collection of samples of hepatitis and reviewing the paper. ME contributed in reviewing the paper. HHA contributed in writing and organization of the whole paper in final form, reviewing and English editing of the paper. All authors have read and approved the final manuscript.

\section{Acknowledgments}

The authors would like to thank Amr Abdulfattah Tohamy, a translator at the Embassy of the Republic of Korea to the State of Kuwait, and EKB editing service for thorough English editing that significantly improved the manuscript. The authors did not receive any funds for this study.

\section{Data availability Statement}

All data collected during this study are included in this article.

\section{Competing Interests}

The authors declare that they have no competing interests.

\section{Publisher's Note}

Veterinary World remains neutral with regard to jurisdictional claims in published institutional affiliation.

\section{References}

1. El-Mahallawy, H.S., Abou-Eisha, A. and Fadel, H. (2012) Coxiella burnetii infections among small ruminants in Ismailia Governorate. SCVMJ, 17 39-50.

2. Yin, M.Y., Qin, S.Y., Tan, Q.D., Feng, S.Y., Liu, G.X., Zhou, D.H. and Zhu, X.Q. (2015) First report of Coxiella burnetii seroprevalence in Tibetan sheep in China. Vector Borne Zoonotic Dis., 15(7): 419-422.

3. Eldin, C., Mélenotte, C., Mediannikov, O., Ghigo, E., Million, M., Edouard, S., Mege, J.L., Maurin, M. and Raoult, D. (2017) From Q fever to Coxiella burnetii infection: A paradigm change. Clin. Microbiol. Rev., 30(1): 115-190.

4. Mori, M. and Roest, H.J. (2018) Farming, Q fever and public health: Agricultural practices and beyond. Arch. Public Health, 76(1): 1-9. 
5. Johnson, S.A., Kaneene, J.B., Asare-Dompreh, K., Tasiame, W., Mensah, I.G., Afakye, K., Simpson, S.V. and Addo, K. (2019) Seroprevalence of Q fever in cattle, sheep and goats in the Volta region of Ghana. Vet. Med. Sci., 5(3): 402-411.

6. Mobarez, A.M., Amiri, F.B. and Esmaeili, S. (2017) Seroprevalence of Q fever among human and animal in Iran; a systematic review and meta-analysis. PLoS Negl. Trop. Dis., 11(4): e0005521.

7. Selim, A., Ali, A.F., Moustafa, S.M. and Ramadan, E. (2018) Molecular and serological data supporting the role of Q fever in abortions of sheep and goats in Northern Egypt. Microb. Pathog., 125: 272-275.

8. Nusinovici, S., Frössling, J., Widgren, S., Beaudeau, F. and Lindberg, A. (2015) Q fever infection in dairy cattle herds: Increased risk with high wind speed and low precipitation. Epidemiol. Infect., 143(15): 3316-3326.

9. Anastácio, S., Carolino, N., Sidi-Boumedine, K. and da Silva, G.J. (2016) Q fever dairy herd status determination based on serological and molecular analysis of bulk tank milk. Transbound. Emerg. Dis., 63(2): e293-e300.

10. Karagul, M.S., Malal, M.E. and Akar, K. (2019) Seroprevalence of Q fever in sheep and goats from the Marmara region, Turkey. J. Vet. Res., 63(4): 527-532.

11. Van den Brom, R., van Engelen, E., Roest, H.I.J., van der Hoek, W. and Vellema, P. (2015) Coxiella burnetii infections in sheep or goats: An opinionated review. Vet. Microbiol., 181(1-2): 119-129.

12. Wielders, C.C., Boerman, A.W., Schimmer, B., van den Brom, R., Notermans, D.W., van der Hoek, W. and Schneeberger, P.M. (2015) Persistent high IgG phase I antibody levels against Coxiella burnetii among veterinarians compared to patients previously diagnosed with acute $\mathrm{Q}$ fever after three years of follow-up. PLoS One, 10(1): e0116937.

13. Cruz, R., Esteves, F., Vasconcelos-Nóbrega, C., Santos, C., Ferreira, A.S., Mega, C., Coelho, A.C., Vala, H. and Mesquita, J.R. (2018) Outbreaks of abortions by Coxiella burnetii in small ruminant flocks and a longitudinal serological approach on archived bulk tank milk suggest $Q$ fever emergence in Central Portugal. Transbound. Emerg. Dis., 65(4): 972-975.

14. Khalifa, N.O., El-Hofy, F.I., Fahmy, H.A., Sobhy, M. and Agag, M. (2016) Seroprevalence and molecular detection of Coxiella burnetii infection in sheep, goats and human in Egypt. ISOI J. Microbiol. Biotechnol. Food Sci., 2: 1-7.

15. Tozer, S. (2015) Epidemiology, Diagnosis and Prevention of Q Fever in Queensland, Ph.D. Thesis. School of Medicine, The University of Queensland, Queensland.

16. Jansen, A.F., Raijmakers, R.P.H., Keijmel, S.P., van der Molen, R.G., Vervoort, G.M., van der Meer, J.W.M., van Deuren, M. and Bleeker-Rovers, C.P. (2018) Autoimmunity and B-cell dyscrasia in acute and chronic Q fever: A review of the literature. Eur. J. Intern. Med., 54(12): 6-12.

17. Angelakis, E. and Raoult, D. (2010) Q fever. Vet. Microbiol., 140(3-4): 297-309.

18. Dupont, H.T., Thirion, X. and Raoult, D. (1994) Q fever serology: Cutoff determination for microimmunofluorescence. Clin. Diagn. Lab. Immunol., 1(2): 189-196.

19. Arabac1, P., Ekşi, F. and Bayram, A. (2017) Investigation of Brucella and Coxiella burnetii antibodies among humans at risk and control groups living in Southeastern Turkey. Eur. J. Ther., 23(3): 111-116.

20. Klemmer, J., Njeru, J., Emam, A., El-Sayed, A., Moawad, A.A., Henning, K., Elbeskawy, M.A., Sauter-Louis, C., Straubinger, R.K., Neubauer, H. and El-Diasty, M.M. (2018) Q fever in Egypt: Epidemiological survey of Coxiella burnetii specific antibodies in cattle, buffaloes, sheep, goats and camels. PLoS One, 13(2): e0192188.

21. Njeru, J., Henning, K., Pletz, M.W., Heller, R. and Neubauer, H. (2016) Q fever is an old and neglected zoonotic disease in Kenya: A systematic review. BMC Public Health, 16(1): 297.

22. Pirouz, H.J., Mohammadi, G., Mehrzad, J., Azizzadeh, M. and Shirazi, M.H.N. (2015) Seroepidemiology of Q fever in one-humped camel population in Northeast Iran. Trop. Anim. Health Prod., 47(7): 1293-1298.

23. Agerholm, J.S. (2013) Coxiella burnetii associated reproductive disorders in domestic animals-a critical review. Acta Vet. Scand., 55(1): 13.

24. Szymańska-Czerwińska, M., Galińska, E.M., Niemczuk, K. and Knap, J.P. (2015) Prevalence of Coxiella burnetii infection in humans occupationally exposed to animals in Poland. Vector Borne Zoonotic Dis., 15(4): 261-267.

25. Jamshidi, A., Razmyar, J. and Borji, S. (2014) Identification of Coxiella burnetii by touch-down PCR assay in unpasteurized milk and dairy products in North-East of Iran. Iran. J. Vet. Med., 8(1): 15-19.

26. Das, D.P., Malik, S.V.S., Rawool, D.B., Das, S., Shoukat, S., Gandham, K., Saxena, S., Singh, R., Doijad, S.P. and Barbuddhe, S.B. (2014) Isolation of Coxiella burnetii from bovines with history of reproductive disorders in India and phylogenetic inference based on the partial sequencing of IS1111 element. Infect. Genet. Evol., 22: 67-71.

27. Vaidya, V., Malik, S.V.S., Kaur, S., Kumar, S. and Barbuddhe, S.B. (2008) Comparison of PCR, immunofluorescence assay, and pathogen isolation for diagnosis of Q fever in humans with spontaneous abortions. J. Clin. Microbiol., 46(6): 2038-2044.

28. Echeverría, G., Reyna-Bello, A., Minda-Aluisa, E., Celi-Erazo, M., Olmedo, L., García, H.A., GarciaBereguiain, M.A. and de Waard, J.H. (2019) Serological evidence of Coxiella burnetii infection in cattle and farm workers: Is $\mathrm{Q}$ fever an underreported zoonotic disease in Ecuador? Infect. Drug Resist., 12: 701.

29. De Bruin, A., de Groot, A., de Heer, L., Bok, J., Wielinga, P.R., Hamans, M., van Rotterdam, B.J. and Janse, I. (2011) Detection of Coxiella burnetii in complex matrices by using multiplex quantitative PCR during a major Q fever outbreak in the Netherlands. Appl. Environ. Microbiol., 77(18): 6516-6523.

30. Jang, Y.R., Song, J.S., Jin, C.E., Ryu, B.H., Park, S.Y., Lee, S.O., Choi, S.H., Kim, Y.S., Woo, J.H., Song, J.K., Shin, Y. and Kim, S.H. (2018) Molecular detection of Coxiella burnetii in heart valve tissue from patients with culture-negative infective endocarditis. Medicine, 97(34): e11881.

31. Mares-Guia, M.A.M., Guterres, A., Rozental, T., Dos Santos Ferreira, M. and Lemos, E.R.S. (2018) Clinical and epidemiological use of nested PCR targeting the repetitive element IS1111 associated with the transposase gene from Coxiella burnetii. Braz. J. Microbiol., 49(1): 138-143.

32. Setiyono, A., Ogawa, M., Cai, Y., Shiga, S., Kishimoto, T. and Kurane, I. (2005) New criteria for immunofluorescence assay for Q fever diagnosis in Japan. J. Clin. Microbiol., 43(11): 5555-5559.

33. Marrie, T.J. and Mege, J.L. (2015) Coxiella, in Molecular Medical Microbiology. Elsevier, Netherlands. p1941-1972.

34. Melenotte, C., Protopopescu, C., Million, M., Edouard, S., Carrieri, M.P., Eldin, C., Angelakis, E., Djossou, F., Bardin, N., Fournier, P.E., Mège, J.L. and Raoult, D. (2018) Clinical features and complications of Coxiella burnetii infections from the French national reference center for $\mathrm{Q}$ fever. JAMA Netw. Open, 1(4): e181580.

35. McQuiston, J.H., Childs, J.E. and Thompson, H.A. (2002) Q fever. J. Am. Vet. Med. Assoc., 221(6): 796-799.

36. Fournier, P.E., Marrie, T.J. and Raoult, D. (1998) Diagnosis of Q fever. J. Clin. Microbiol., 36(7): 1823-1834.

37. Mazyad, S. and Hafez, A.O. (2007) Q fever (Coxiella burnetii) among man and farm animals in North Sinai, Egypt. J. Egypt. Soc. Parasitol., 37(1): 135-142.

38. Hussien, M.O., ElFahal, A.M., Enan, K.A., Taha, K.M., Mohammed, M.S., Salih, D.A., Mohammadain, S.I., Saeed, A.A. and El-Hussein, A.M. (2012) Seroprevalence of Q fever in goats in the Sudan. Vet. World, 5(7): 394-397.

39. Berri, M., Souriau, A., Crosby, M., Crochet, D., Lechopier, P. and Rodolakis, A. (2001) Relationships between the shedding of Coxiella burnetii, clinical signs and serological responses of 34 sheep. Vet. Rec., 148(16): 502-505. 
40. Cong, W. (2015) Coxiella burnetii (Q fever) infection in farmed ruminants in three northeastern provinces and inner Mongolia autonomous region, China. Vector Borne Zoonotic Dis., 15(8): 512-514.

41. Chakrabartty, A., Bhattacharjee, P.K., Sarker, R.R., Rahman, A.K.M., Henning, K., Neubauer, H. and Rahman, M.S. (2016) Prevalence of Coxiella burnetii infection in cattle, black bengal goats and ticks in Bangladesh. Bangladesh J. Vet. Med., 14(1): 65-68.

42. Mostafavi, E., Molaeipoor, L., Esmaeili, S., Ghasemi, A., Kamalizad, M., Behzadi, M.Y., Naserifar, R., Rohani, M. and Shahraki, A.H. (2019) Seroprevalence of Q fever among high-risk occupations in the Ilam Province, the West of Iran. PLoS One, 14(2): e0211781.

43. Berktaş, M., Ceylan, E., Yaman, G., Çiftci, I.H. (2011) Seroprevalence of Coxiella burnetii antibodies in high risk groups in eastern Turkey. Turk. Klinikleri J. Med. Sci., 31(1): 45-50.

44. Sun, W.W., Cong, W., Li, M.H., Wang, C.F., Shan, X.F. and Qian, A.D. (2016) Coxiella burnetii seroprevalence and risk factors in cattle farmers and farm residents in three Northeastern Provinces and inner Mongolia autonomous region, China. Biomed Res. Int., 2016: 7059196.

45. Vickers, N.J. (2017) Animal communication: When i'm calling you, will you answer too? Curr. Biol., 27(14): R713-R715.

46. Esmaeili, S., Pourhossein, B., Gouya, M.M., Amiri, F.B. and Mostafavi, E. (2014) Seroepidemiological survey of Q fever and brucellosis in Kurdistan Province, Western Iran. Vector Borne Zoonotic Dis., 14(1): 41-45.

47. Anderson, A., Bijlmer, H., Fournier, P.E., Graves, S., Hartzell, J., Kersh, G.J., Limonard, G., Marrie, T.J., Massung, R.F., McQuiston, J.H., Nicholson, W.L., Paddock, C.D. and Sexton, D.J. (2013) Diagnosis and management of Q fever-United States, 2013: Recommendations from $\mathrm{CDC}$ and the Q fever working group. Morb. Mortal. Wkly. Rep., 62(3): p. 1-29.

48. Khalili, M., Shahabi-Nejad, N. and Golchin, M. (2010) Q fever serology in febrile patients in Southeast Iran. Trans. R. Soc. Trop. Med. Hyg., 104(9): 623-624.

49. Meredith, A., Cleaveland, S.C., Denwood, M.J., Brown, J.K. and Shaw, D.J. (2015) Coxiella burnetii (Q-fever) seroprevalence in prey and predators in the United Kingdom: Evaluation of infection in wild rodents, foxes and domestic cats using a modified ELISA. Transbound. Emerg. Dis., 62(6): 639-649.

50. Fenga, C., Gangemi, S., De Luca, A., Calimeri, S., Lo Giudice, D., Pugliese, M., Licitra, F., Alibrandi, A. and Costa, C. (2015) Seroprevalence and occupational risk survey for Coxiella burnetii among exposed workers in Sicily, Southern Italy. Int. J. Occup. Med. Environ. Health, 28(5): 901.

51. Kaplan, M.M. and Bertagna, P. (1955) The geographical distribution of Q fever. Bull. World Health Organ., 13(5): 829.

52. Rafyi, A. and Maghami, G. (1954) Presence of Q fever in Iran. Bull. Soc. Pathol. Exotique, 47(6): 766-768.

53. Fard, S.N. and Khalili, M. (2011) PCR-detection of Coxiella burnetii in ticks collected from sheep and goats in southeast Iran. Iran. J. Arthropod Borne Dis., 5(1): 1.

54. Noden, B.H., Tshavuka, F.I., van der Colf, B.E., Chipare, I. and Wilkinson, R. (2014) Exposure and risk factors to Coxiella burnetii, spotted fever group and typhus group Rickettsiae, and Bartonella henselae among volunteer blood donors in Namibia. PLoS One, 9(9): e108674.

55. Dupuis, G., Vouilloz, M., Péter, O. Mottiez, M.C. (1985) Incidence of Q fever in Valais. Rev. Méd. Suisse Romande, 105(10): 949.

56. Morroy, G., van der Hoek, W., Albers, J., Coutinho, R.A.,
Bleeker-Rovers, C.P. and Schneeberger, P.M. (2015) Population screening for chronic Q-fever seven years after a major outbreak. PLoS One, 10(7): e0131777.

57. Ljutić, D., Radovniković, G. and Kurir, T.T. (2007) Acute renal failure associated with rhabdomyolysis in acute Q fever. Ren. Fail., 29(6): 743-746.

58. Vizinho, R., Branco, M., Amaral, T., Gil1, C., Gonçalves, M., Rodrigues, I., Negrão, A.P. and Barata, J.D. (2012) Chronic Q fever in two haemodialysis patients. Port. J. Nephrol. Hypertens., 26(4): 298-303.

59. Oh, M., Baek, S., Lee, S.O., Yu, E. and Ryu, J.S. (2012) A case of acute Q fever hepatitis diagnosed by F-18 FDG PET/CT. Nucl. Med. Mol. Imaging, 46(2): 125-128.

60. Hofmann, C.E. and Heaton, J.W. (1982) Q fever hepatitis: Clinical manifestations and pathological findings. Gastroenterology, 83(2): 474-479.

61. Lai, C.H., Chin, C., Chung, H.C., Huang, C.K., Chen, W.F., Yang, Y.T., Chen, W. and Lin, H.H. (2007) Acute Q fever hepatitis in patients with and without underlying hepatitis B or C virus infection. Clin. Infect. Dis., 45(5): e52-e59.

62. Derrick, E. (1937) Q fever, a new fever entity: Clinical features, diagnosis and laboratory investigation. Med. J. Aust., 2(8): 281-299.

63. Dupont, H., Hornick, R.B., Levin, H.S., Rapoport, M.I. and Woodward, T.E. (1971) Q fever hepatitis. Ann. Intern. Med., 74(2): 198-206.

64. Srigley, J., Vellend, H., Palmer, N., Phillips, M.J., Geddie, W.R., Van Nostrand, A.W. and Edwards, V.D. (1985) Q-fever. The liver and bone marrow pathology. Am. J. Surg. Pathol., 9(10): 752-758.

65. Alkan, W., Evenchik, Z. and Eshchar, J. (1965) Q fever and infectious hepatitis. Am. J. Med., 38(1): 54-61.

66. Hoover, T., Vodkin, M. and Williams, J. (1992) A Coxiella burnetti repeated DNA element resembling a bacterial insertion sequence. J. Bacteriol., 174(17): 5540-5548.

67. Rodolakis, A. (2009) Q fever in dairy animals. Ann. N. Y. Acad. Sci., 1166(1): 90-93.

68. Panning, M., Kilwinski, J., Greiner-Fischer, S., Peters, M., Kramme, S., Frangoulidis, D., Meyer, H., Henning, K. and Drosten, C. (2008) High throughput detection of Coxiella burnetii by real-time PCR with internal control system and automated DNA preparation. BMC Microbiol., 8(1): 77.

69. Pradeep, J., Stephen, S., Ambroise, S. and Gunasekaran, D. (2017) Diagnosis of acute $\mathrm{Q}$ fever by detection of Coxiella burnetii DNA using real-time PCR, employing a commercial genesig easy kit. J. Clin. Diagn. Res., 11(9): DC10.

70. Yeboah, C.N. (2016) Q Fever Infection in Patients with Febrile Illness at Selected Healthcare Facilities in Ghana. University of Ghana, Ghana.

71. Schneeberger, P.M., Hermans, M.H., van Hannen, E.J., Schellekens, J.J., Leenders, A.C.A. and Wever, P.C. (2010) Real-time PCR with serum samples is indispensable for early diagnosis of acute Q fever. Clin. Vaccine. Immunol., 17(2): 286-290.

72. Jung, B.Y., Seo, M.G., Lee, S.H., Byun, J.W., Oem, J.K. and Kwak, D. (2014) Molecular and serologic detection of Coxiella burnetii in native Korean goats (Capra hircus coreanae). Vet. Microbiol., 173(1-2): 152-155.

73. Nokhodian, Z., Feizi, A., Khalili, M., Ataei, B. and Moradi, A. (2018) Molecular evidence and risk factors of Coxiella burnetii among seropositive high-risk individuals in the center of Iran. Comp. Immunol. Microbiol. Infect. Dis., 61: 34-37.

74. Hazlett, M.J., McDowall, R., DeLay, J., Stalker, M., McEwen, B., van Dreumel, T., Spinato, M., Binnington, B., Slavic, D., Carman, S. and Cai, H.Y. (2013) A prospective study of sheep and goat abortion using real-time polymerase chain reaction and cut point estimation shows Coxiella burnetii and Chlamydophila abortus infection concurrently with other major pathogens. J. Vet. Diagn. Invest., 25(3): 359-368. 